\title{
GRAIN-REFINING ABILITY OF ULTRA-RAPID ANNEALING FOR LOW-CARBON STEEL: SEVERE PLASTIC DEFORMATION
}

\author{
SPOSOBNOST UDROBNENJA ZRN PRI ZELO HITREM ŽARJENJU \\ MALOOGLJIČNEGA JEKLA PO VELIKI PLASTIČNI \\ DEFORMACIJI
}

\author{
Mohammad Ali Mostafaei, Mohsen Kazeminezhad \\ Sharif University of Technology, Department of Materials Science and Engineering, Azadi Avenue, Tehran, Iran \\ mkazemi@sharif.edu \\ Prejem rokopisa - received: 2015-12-19; sprejem za objavo - accepted for publication: 2016-02-03
}

doi: $10.17222 /$ mit. 2015.350

\begin{abstract}
To study the grain-refinement ability of ultra-rapid annealing (URA), heating rates from $0.3{ }^{\circ} \mathrm{C} / \mathrm{s}$ up to $1200{ }^{\circ} \mathrm{C} / \mathrm{s}$ with conventional annealing and URA in the intercritical temperature range were performed on severely deformed low-carbon steel. The results show that recrystallization in conventional annealing is completed below the critical temperature of $A c_{1}$ without grain refinement. URA up to $730{ }^{\circ} \mathrm{C}$ at a heating rate of $200{ }^{\circ} \mathrm{C} / \mathrm{s}$ causes grain refinement due to full interaction between the recrystallization and phase transformation. URAs up to $730{ }^{\circ} \mathrm{C}$ with heating rates of $600{ }^{\circ} \mathrm{C} / \mathrm{s}$ and $1000{ }^{\circ} \mathrm{C} / \mathrm{s}$ lead to partial grain refinement and no grain refinement, respectively. During annealing with a heating rate of $1200{ }^{\circ} \mathrm{C} / \mathrm{s}$, the temperature should reach $760{ }^{\circ} \mathrm{C}$ for the occurrence of recrystallization leading to grain refinement. The sample URAed at $600{ }^{\circ} \mathrm{C} / \mathrm{s}$ up to $730{ }^{\circ} \mathrm{C}$ shows the maximum hardness due to fine grains being partially formed.

Keywords: conventional annealing, ultra-rapid annealing, interaction, severe plastic deformation

Za študij sposobnosti udrobnjenja zrn pri zelo hitrem žarjenju, so bile uporabljene hitrosti segrevanja od $0,3{ }^{\circ} \mathrm{C} / \mathrm{s}$ do $1200{ }^{\circ} \mathrm{C} / \mathrm{s}$ pri običajnem in zelo hitrem žarjenju v interkritičnem temperaturnem območju na močno deformiranem maloogljičnem jeklu. Rezultati kažejo, da je rekristalizacija pri konvencionalnem žarjenju zaključena pod kritično temperaturo $A c_{1}$ brez udrobnjenja zrn. Zelo hitro žarjenje do $730{ }^{\circ} \mathrm{C}$ pri hitrosti ogrevanja $200{ }^{\circ} \mathrm{C} / \mathrm{s}$ povzroči udrobnjenje zrn, zaradi polne interakcije med rekristalizacijo in fazno premeno. Zelo hitro žarjenje do $730{ }^{\circ} \mathrm{C}$, s hitrostjo ogrevanja $600{ }^{\circ} \mathrm{C} / \mathrm{s}$ in $1000{ }^{\circ} \mathrm{C} / \mathrm{s}$ povzroči delno udrobnjenje zrn oz. udrobnjenja zrn ni. Med ogrevanjem s hitrostjo $1200^{\circ} \mathrm{C} / \mathrm{s}$ je potrebno doseči temperaturo $760{ }^{\circ} \mathrm{C}$, da se pojavi rekristalizacija, ki povzroči udrobnitev zrn. Vzorec po zelo hitrem žarjenju z $600{ }^{\circ} \mathrm{C} / \mathrm{s}$ do $730{ }^{\circ} \mathrm{C}$ kaže maksimalno trdoto zaradi delnega nastanka drobnih zrn.

Ključne besede: konvencionalno žarjenje, zelo hitro žarjenje, interakcija, močna plastična deformacija
\end{abstract}

\section{INTRODUCTION}

Conventional annealing of deformed steel with a slow heating rate (usually below $10{ }^{\circ} \mathrm{C} / \mathrm{s}$ ) ${ }^{1}$ causes recovery and recrystallization to occur sequentially by subcritical temperature (below the critical temperature of $\left.\left.A \mathrm{c}_{1}\right)\right)^{2,3}$ This annealing is followed by furnace soaking to complete the recrystallization. ${ }^{3}$ However, in low-carbon steel the grain refinement after conventional annealing needs to combine the steel's chemical composition and the annealing cycle. ${ }^{4,5}$ Also, the phase transformation during conventional annealing in the intercritical temperature range does not influence the grain refinement of deformed low-carbon steel.

On the other hand, ultra-rapid annealing (URA) of steels is a new method that leads to grain refinement in a very short time due to changes in the starting temperature of recrystallization. ${ }^{6-9}$ This condition provides the ability to control the microstructure by means of the simultaneous occurrence of recrystallization and phase transformation. URA shifts the start temperature of recrystallization to higher values near and above $A c_{1}{ }^{3,7-15}$ So, in the intercritical temperature range, recrystalliza- tion and phase transformation proceed concurrently and with a mutual "interaction". The intensity of the interaction depends of the amount of stored energy and determines the final microstructure of the steel. ${ }^{16-18}$ The heating rate controls the recrystallization start temperature and the amount of stored strain energy before the interaction. So, heating rate has a key role in controlling the microstructure and the grain refinement.

In this research, the effect of a slow heating rate $(0.3$ $\left.{ }^{\circ} \mathrm{C} / \mathrm{s}\right)$ up to a high heating rate $\left(1200{ }^{\circ} \mathrm{C} / \mathrm{s}\right)$ in the intercritical temperature range on the final microstructure of the severely deformed low-carbon steel is examined. The steel is subjected to severe plastic deformation to increase its stored strain energy before annealing.

\section{EXPERIMENTAL PART}

The low-carbon steel with $0.05 \mathrm{C}, 0.2 \mathrm{Mn}, 0.011 \mathrm{P}$, $0.007 \mathrm{~S}, 0.055 \mathrm{Al}$ (all in $w / \%$ ) in the form of a sheet with a thickness of $3 \mathrm{~mm}$ is used in this research. The as-received materials were normalized to obtain the spherodized cementite. SPD was performed using two passes of constrained grooved pressing (CGP) on speci- 


\section{MATERIALI IN TEHNOLOGIJE/MATERIALS AND TECHNOLOGY (1967-2017) - 50 LET/50 YEARS}

\section{A. MOSTAFAEI, M. KAZEMINEZHAD: GRAIN-REFINING ABILITY OF ULTRA-RAPID ANNEALING ...}

mens with a size of $80 \times 50 \times 3 \mathrm{~mm}$ in the sheet rolling direction. Each complete pass of CGP imposes an overall strain of 1.16, which contains four alternating stages of pressing grooving in dies and flattening dies. After the first two stages, the specimen is rotated $180^{\circ}$ around the axis perpendicular to the sheet plane and then the two stages are repeated. The direction of the grooving dies is perpendicular to the rolling direction of the as-received sheet. Teflon layers were used as the lubricant between the samples and the dies. More details of the CGP method are given in ${ }^{19,20}$. For ultra-rapid annealing, the samples were machined from both sides up to a thickness of $1.8 \mathrm{~mm}$, and then cut into specimens with a width of $14 \mathrm{~mm}$.

The URA setup is based on resistance heating, which is provided by a high current transformer controlled by a digital control unit. A high current of about 5000 A passes through the sample and increases the temperature that is measured using a thermocouple finely spot welded to the center of the sample, and read with a high-speed data logger at a frequency of 3000. The data is concurrently transferred and saved to a PC, and the temperature-time diagram is drawn simultaneously during URA. Different heating rates were applied up to the desired sample temperature that was then immediately cooled after heating with a rate of about $-700{ }^{\circ} \mathrm{C} / \mathrm{s}$ with a high-speed spray of water and air.

Slow heating rate conventional annealing was carried out in a furnace with a heating rate of about $0.3{ }^{\circ} \mathrm{C} / \mathrm{s}$ without any soaking time. At the desired temperature the samples were removed from the furnace and quenched as mentioned above.

After annealing, a hardness test was performed using $30 \mathrm{~kg}$ Vickers and then the samples were prepared for microstructural examinations, from thickness in the longitudinal direction.

\section{RESULTS AND DISCUSSION}

The microstructure of the as-received steel consists of ferrite grains (a mean grain size of about $80 \mu \mathrm{m}$ ) with dispersed carbide particles and was free of pearlite. After SPD, the mean grain size was reduced to about $30 \mu \mathrm{m}$, and particles were refined and highly dispersed at the grain boundaries and inside the grains (Figure 1).

The microstructure of the SPDed steel after conventional furnace annealing up to $730{ }^{\circ} \mathrm{C}$ (slightly above $A c_{1}$ ) is shown in Figure 2. Several experiments were done by annealing up to different temperatures showed that the $A_{\mathrm{C} 1}$ temperature of the studied steel is about 720 ${ }^{\circ} \mathrm{C}$ and pearlite was observed after heating higher than $720^{\circ} \mathrm{C}$. The microstructure was recrystallized, the grains grew and some of the grains are marked with "A", grown to abnormal size. This shows that recrystallization started before the critical temperature of $A c_{1}$. Figure 3 shows the microstructures of SPDed steel after subcritical conventional annealing up to the temperatures

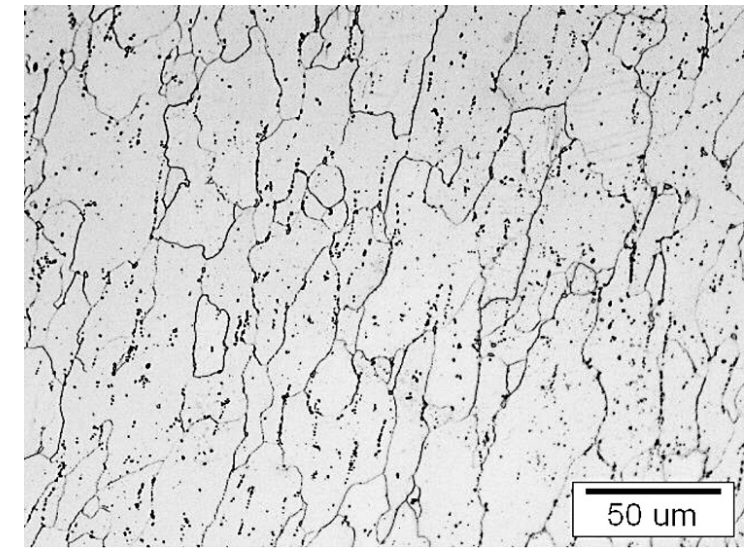

Figure 1: Microstructure of low-carbon steel after SPD Slika 1: Mikrostruktura maloogljičnega jekla po SPD

of $500{ }^{\circ} \mathrm{C}$ and $650{ }^{\circ} \mathrm{C}$. After heating up to $500{ }^{\circ} \mathrm{C}$, the microstructure was similar to that of the SPDed sample and indicated that the recrystallization was not started. In the sample heated to $650{ }^{\circ} \mathrm{C}$, the microstructure is fully recrystallized and the grain size is smaller than in Figure 2. This shows that the start and finish temperatures of the recrystallization during conventional annealing are much below the $A \mathrm{c}_{1}$.

The microstructure of SPDed steel after URA with a heating rate of $200{ }^{\circ} \mathrm{C} / \mathrm{s}$ up to $730{ }^{\circ} \mathrm{C}$ in Figure 4 showed that URA produced grain refinement to an average grain size of $8 \mu \mathrm{m}$.

The scanning electron micrograph (SEM) in Figure 4b indicates the formation of pearlite massively dispersed at recrystallized ferrite grain boundaries. This suggests the full interaction of the ferrite recrystallization and the phase transformation. As the interaction occurs, the kinetics of recrystallization and transformation are increased. ${ }^{3,6,13,16,21}$ The austenite phase nucleates first at the deformed ferrite grain boundaries. ${ }^{22}$ On the other hand, austenite provides a preferred recrystal-

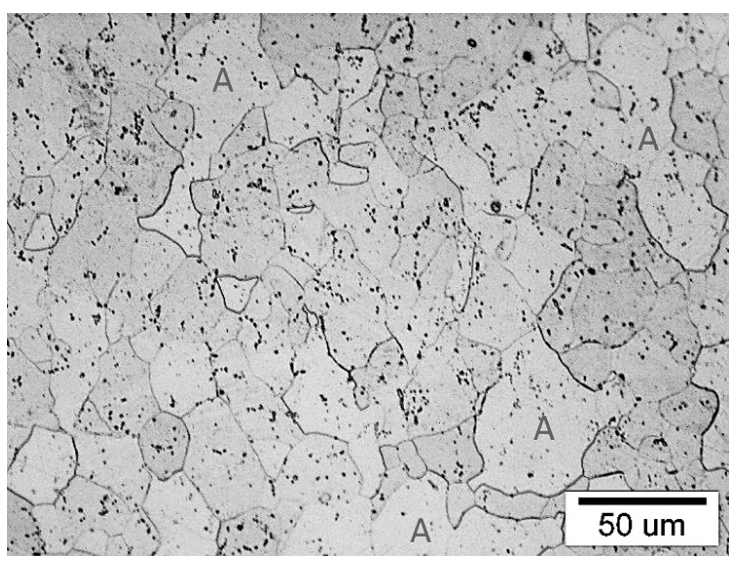

Figure 2: Microstructure of severely deformed steel by furnace annealing up to $730{ }^{\circ} \mathrm{C}$ with heating rate of $0.3{ }^{\circ} \mathrm{C} / \mathrm{s}$, abnormally grown grains are marked with $\mathrm{A}$

Slika 2: Mikrostruktura močno deformiranega jekla po žarjenju v peči na $730{ }^{\circ} \mathrm{C}$ in s hitrostjo segrevanja $0,3{ }^{\circ} \mathrm{C} / \mathrm{s}$, neobičajno velika zrna so označena $\mathrm{z} \mathrm{A}$ 


\section{A. MOSTAFAEI, M. KAZEMINEZHAD: GRAIN-REFINING ABILITY OF ULTRA-RAPID ANNEALING ...}
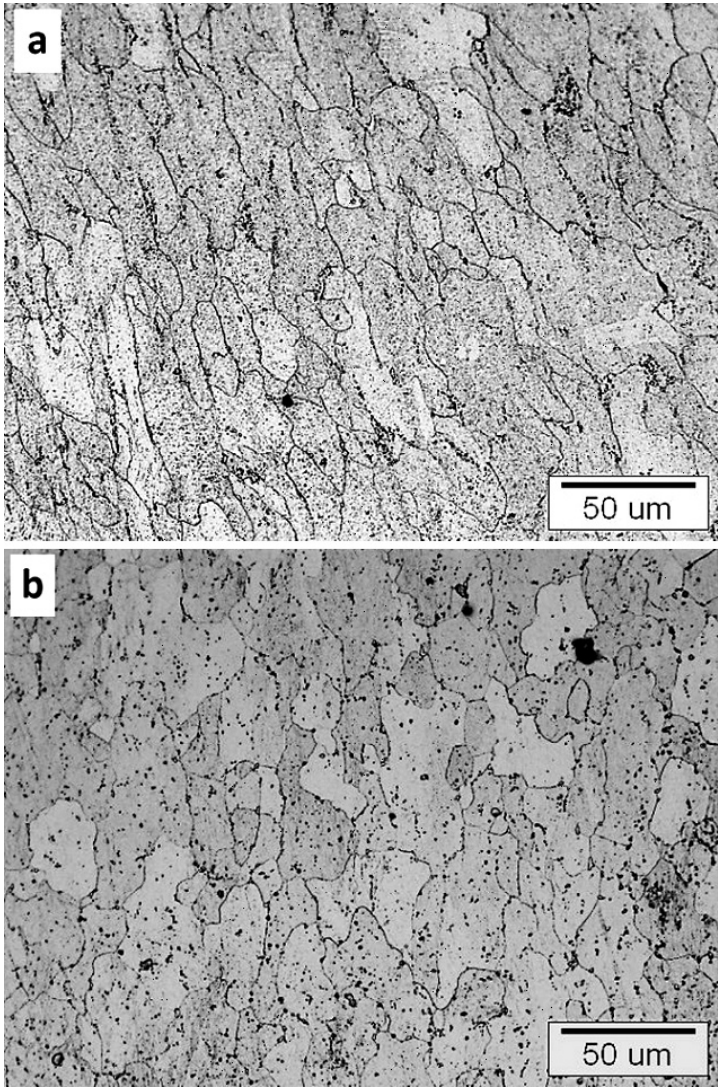

Figure 3: Microstructure of severely deformed steel after furnace annealing with a heating rate of $0.3{ }^{\circ} \mathrm{C} / \mathrm{s}$ : a) $500{ }^{\circ} \mathrm{C}$, and b) $650{ }^{\circ} \mathrm{C}$

Slika 3: Mikrostruktura močno deformiranega jekla po žarjenju v peči s hitrostjo segrevanja $0,3{ }^{\circ} \mathrm{C} / \mathrm{s}$ : a) $500^{\circ} \mathrm{C}$ in b) $650{ }^{\circ} \mathrm{C}$

lization nucleation site for the non-recrystallized ferrite. So, fine recrystallized ferrite grains are surrounded by austenite phases (which are transformed to pearlite during cooling) and their growth is inhibited and the microstructure with refined grains is formed. It should be noted that the transformation of austenite to pearlite during cooling was accelerated by the small size of the austenite grains. ${ }^{12,23,24}$

URA with a heating rate of $600{ }^{\circ} \mathrm{C} / \mathrm{s}$ up to $730{ }^{\circ} \mathrm{C}$ does not show a homogeneous grain refinement. This
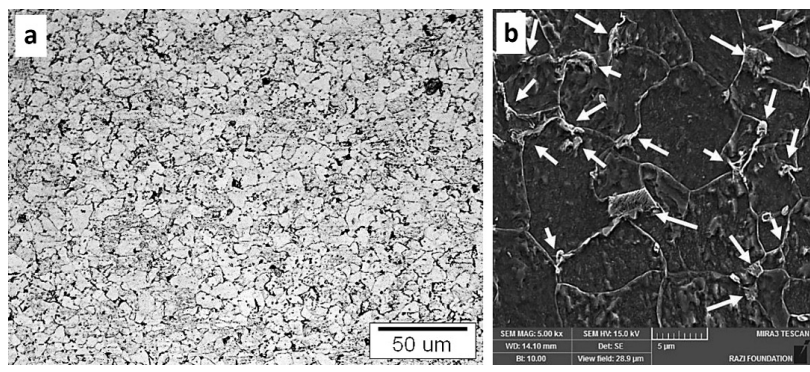

Figure 4: Microstructure of severely deformed steel after URA up to $730^{\circ} \mathrm{C}$ with heating rate of $200{ }^{\circ} \mathrm{C} / \mathrm{s}$ : a) optical microscopy image, and b) SEM image, arrows mark pearlites

Slika 4: Mikrostruktura močno deformiranega jekla po zelo hitrem žarjenju na $730{ }^{\circ} \mathrm{C}$, s hitrostjo segrevanja $200^{\circ} \mathrm{C} / \mathrm{s}$ : a) posnetek s svetlobno mikroskopijo in b) SEM-posnetek, puščice označujejo perlite

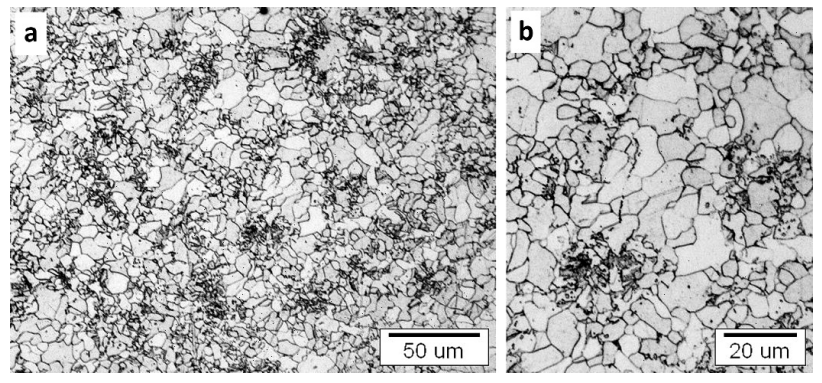

Figure 5: a) Microstructure of severely deformed steel after URA up to $730{ }^{\circ} \mathrm{C}$ with heating rate of $600{ }^{\circ} \mathrm{C} / \mathrm{s}$, b) higher magnification of a) Slika 5: a) Mikrostruktura močno deformiranega jekla po zelo hitrem žarjenju do $730{ }^{\circ} \mathrm{C}$ s hitrostjo segrevanja $600^{\circ} \mathrm{C} / \mathrm{s}$ in b) večja povečava a)

microstructure (Figure 5) consists of two-sized grains of $10 \mu \mathrm{m}$ and $2 \mu \mathrm{m}$. It can be seen that a partial grain refinement occurred due to incomplete recrystallization, and pearlite surrounded by the locally recrystallized ferrite grains were formed.

This shows a localized interaction. In comparison with the sample heated with $200{ }^{\circ} \mathrm{C} / \mathrm{s}$, the heating rate of $600{ }^{\circ} \mathrm{C} / \mathrm{s}$ delays the start temperature of the recrystallization slightly above $A c_{1}$. During URA, austenite was formed and then recrystallization took place. In this situation the interaction between ferrite recrystallization and the formation of austenite is localized around recently formed austenite.

The microstructure shown in Figure $\mathbf{6}$ is from the SPDed sample URA treated with heating at $1000{ }^{\circ} \mathrm{C} / \mathrm{s}$ up to $730{ }^{\circ} \mathrm{C}$ and shows no recrystallization and the grain size of about $30 \mu \mathrm{m}$ is similar to the grain size of the SPDed sample before URA. A very high heating rate of $1000{ }^{\circ} \mathrm{C} / \mathrm{s}$ shifts the start temperature of the recrystallization higher than $730{ }^{\circ} \mathrm{C}$. However, the transformation occurred and the pearlite phase was formed around the non-recrystallized ferrite grains (Figure 6b).

For the occurrence of recrystallization with a high heating rate, the peak temperature of URA should be increased in proportion to the heating rate. For example, from the microstructure in Figure 7, for URA with
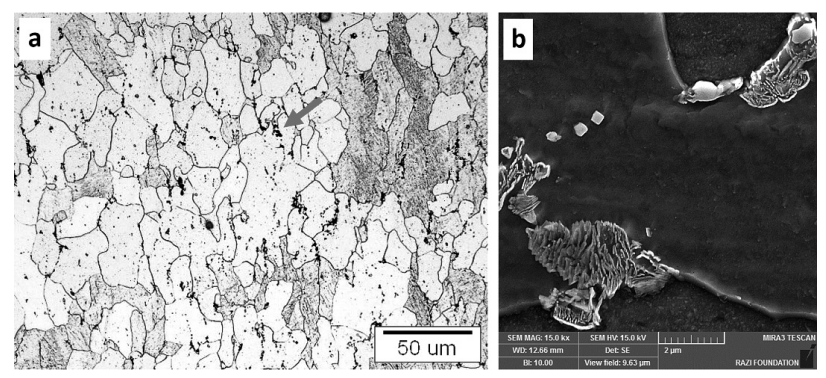

Figure 6: Microstructure of severely deformed steel after URA up to $730{ }^{\circ} \mathrm{C}$ with the heating rate of $1000{ }^{\circ} \mathrm{C} / \mathrm{s}$ : a) optical microscopy image, b) SEM image of dark phases indicated by arrow in a)

Slika 6: Mikrostruktura močno deformiranega jekla po zelo hitrem žarjenju na $730{ }^{\circ} \mathrm{C}$, s hitrostjo segrevanja $1000{ }^{\circ} \mathrm{C} / \mathrm{s}$ : a) posnetek s svetlobno mikroskopijo in b) SEM-posnetek temnih faz v a), označeni so $s$ puščico 


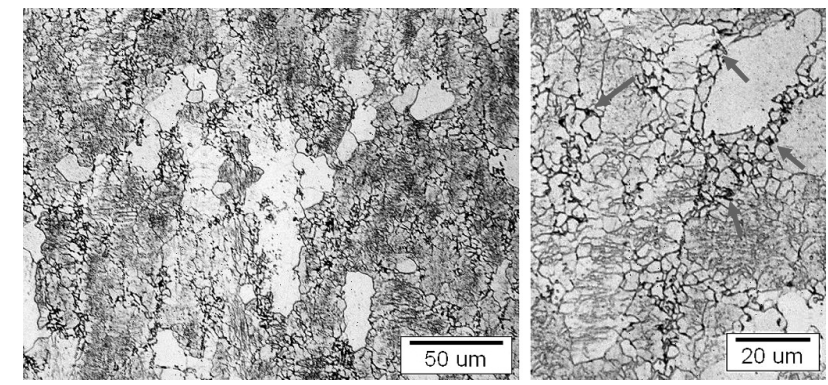

Figure 7: a) Microstructure of severely deformed steel after URA up to $760{ }^{\circ} \mathrm{C}$ with heating rate of $1200{ }^{\circ} \mathrm{C} / \mathrm{s}$, b) higher magnification of a), arrows marks the pearlite

Slika 7: a) Mikrostruktura močno deformiranega jekla po zelo hitrem žarjenju na $760{ }^{\circ} \mathrm{C}$, s hitrostjo segrevanja $1200^{\circ} \mathrm{C} / \mathrm{s}$, b) večja povečava a), puščice označujejo perlit

heating rate of $1200{ }^{\circ} \mathrm{C} / \mathrm{s}$ up to $760{ }^{\circ} \mathrm{C}$ it is clear that there is the start of recrystallization.

In this condition, similar to Figure 5, transformation is started before recrystallization. During URA, the austenite phases were formed and then the recrystallization localized around them, causing the formation of the two-sized-grains microstructure with the sizes of $30 \mu \mathrm{m}$ and $2 \mu \mathrm{m}$. The austenite transformed to pearlite during cooling is marked with arrows in Figure $\mathbf{7 b}$.

The hardness of the specimens treated conventionally and with URA are shown in Figure 8.

The sample heated with $600{ }^{\circ} \mathrm{C} / \mathrm{s}$ up to $730{ }^{\circ} \mathrm{C}$ has the highest hardness because of the partial formation of fine grains and the formation of pearlite in the microstructure. The composite-like microstructure of this sample is responsible for its high hardness. For a similar reason, the sample heated with $1200{ }^{\circ} \mathrm{C} / \mathrm{s}$ up to $760{ }^{\circ} \mathrm{C}$ also has a relatively high value of hardness of about 183 HV.

The hardness of the conventionally annealed samples confirms the described microstructure. The sample annealed up to $550{ }^{\circ} \mathrm{C}$ has a similar hardness to that before annealing. This confirms the absence of recrystallization, as mentioned before. For the samples annealed up to $650{ }^{\circ} \mathrm{C}$, the hardness is sharply reduced due to recrystallization.

\section{CONCLUSIONS}

The effect of the heating rate on the grain refinement is investigated with conventional annealing and ultrarapid annealing for severely deformed low-carbon steel and the following conclusions can be drawn:

- In conventional annealing with a heating rate of $0.3{ }^{\circ} \mathrm{C} / \mathrm{s}$, recrystallization is completed below the critical temperature of $A \mathrm{c}_{1}$, and the absence of grain refinement is confirmed with hardness values.

- URA with the heating rate of $200{ }^{\circ} \mathrm{C} / \mathrm{s}$ up to $730{ }^{\circ} \mathrm{C}$ leads to full grain refinement due to the full interaction between ferrite recrystallization and austenite formation.

- At $730{ }^{\circ} \mathrm{C}$, achieved with URA, the increasing of the heating rate to $600{ }^{\circ} \mathrm{C} / \mathrm{s}$ causes a partial grain

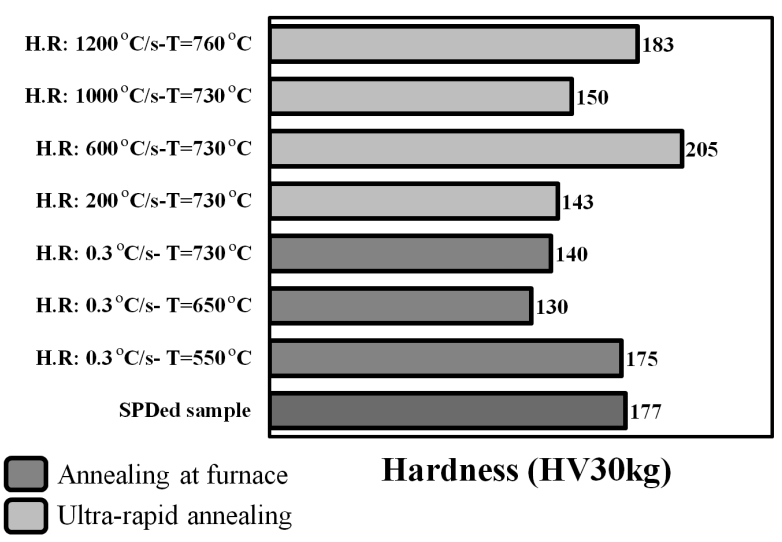

Figure 8: Hardness values of SPDed steel before annealing and after conventional and ultra-rapid annealing.

Slika 8: Vrednosti za trdoto SPD jekla pred žarjenjem in po konvencionalnem ter po zelo hitrem žarjenju

refinement due to localized interaction. The sample in this condition shows the maximum hardness value of $205 \mathrm{Hv}$.

- By increasing the heating rate to $1000{ }^{\circ} \mathrm{C} / \mathrm{s}$, no recrystallization occurs at the temperature of $730{ }^{\circ} \mathrm{C}$.

- Temperature should be increased in proportion to the heating rate in order to start the recrystallization and the occurrence of grain refinement, such as those that occurred for the sample URAed with $1200^{\circ} \mathrm{C} / \mathrm{s}$ up to $760{ }^{\circ} \mathrm{C}$.

\section{Acknowledgement}

The authors wish to thank the research board of Sharif University of Technology for the financial support and the provision of the research facilities used in this work.

\section{REFERENCES}

${ }^{1}$ Q. Meng, J. Li, H. Zheng, High-efficiency fast-heating annealing of a cold-rolled dual-phase steel, Materials and Design, 58 (2014), 194-197, doi:10.1016/j.matdes.2014.01.055

${ }^{2}$ A. Karmakar, D. Chakrabarti, Comparison between Conventional Annealing and Rapid-Transformation Annealing of Low-Carbon Steel, International Journal of Metallurgical Engineering, 2 (2013), 137-141, doi:10.5923/j.ijmee.20130202.04

${ }^{3}$ P. Li, J. Li, Q. Meng, W. Hu, D. Xu, Effect of heating rate on ferrite recrystallization and austenite formation of cold-roll dual phase steel, Journal of Alloys and Compounds, 578 (2013), 320-327, doi:10.1016/j.jallcom.2013.05.226

${ }^{4} \mathrm{H}$. Shi, Investigations of the effect of ultra-rapid heating on the softening of a cold rolled low-carbon steel, University of Wollongong, Wollongong 1990, 245 (PhD Thesis)

${ }^{5}$ Z. Hou, Y. Xu, D. Wu, Recrystallization of ultra-low carbon steel sheet after ultra-rapid annealing, Acta Metallurgica Sinica, 48 (2012), 1057, doi:10.3724/SP.J.1037.2012.00115

${ }^{6}$ C. Lesch, P. Álvarez, W. Bleck, J. Gil Sevillano, Rapid Transformation Annealing: a Novel Method for Grain Refinement of ColdRolled Low-Carbon Steels, Metallurgical and Materials Transactions A, 38 (2007), 1882-1890, doi:10.1007/s11661-006-9052-y 


\section{MATERIALI IN TEHNOLOGIJE/MATERIALS AND TECHNOLOGY (1967-2017) - 50 LET/50 YEARS}

\section{A. MOSTAFAEI, M. KAZEMINEZHAD: GRAIN-REFINING ABILITY OF ULTRA-RAPID ANNEALING ...}

${ }^{7}$ V. Massardier, A. Ngansop, D. Fabregue, J. Merlin, Identification of the parameters controlling the grain refinement of ultra-rapidly annealed low carbon Al-killed steels, Materials Science and Engineering A, 527 (2010), 5654-5663, doi:10.1016/j.msea.2010.05.024

${ }^{8}$ R. Petrov, J. Sidor, W. Kaluba, L. Kestens, Grain Refinement of a Cold Rolled TRIP Assisted Steel after Ultra Short Annealing, Materials Science Forum, 715-716 (2012), 661-666, doi:10.4028/ www.scientific.net/MSF.715-716.661

${ }^{9}$ D. Muljono, M. Ferry, D. Dunne, Influence of heating rate on anisothermal recrystallization in low and ultra-low carbon steels, Materials Science and Engineering A, 303 (2001), 90-99, doi:10.1016/S0921-5093(00)01882-7

${ }^{10}$ S.S. Gorelik, Recrystallization in Metals and Alloys, MIR Publisher, Moscow 1981, 92

${ }^{11}$ D. Xu, J. Li, Q. Meng, Y. Liu, P. Li, Effect of heating rate on microstructure and mechanical properties of TRIP-aided multiphase steel, Journal of Alloys and Compounds, 614 (2014), 94-101, doi:10.1016/j.jallcom.2014.06.075

${ }^{12}$ H. Azizi-Alizamini, M. Militzer, W. J. Poole, Austenite Formation in Plain Low-Carbon Steels, Metallurgical and Materials Transactions A, 42 (2011), 1544-1557, doi:10.1007/s11661-010-0551-5

${ }^{13} \mathrm{C}$. Zheng, D. Raabe, Interaction between recrystallization and phase transformation during intercritical annealing in a cold-rolled dual-phase steel: A cellular automaton model, Acta Materialia, 61 (2013) 5504-5517, doi:10.1016/j.actamat.2013.05.040

${ }^{14}$ J. Stockemer, P. Vanden Brande, P. Brande, Recrystallization of a cold-rolled low-carbon steel by cold-plasma-discharge rapid annealing, Metallurgical and Materials Transactions A, 34 (2003), 1341-1348, doi:10.1007/s11661-003-0245-3

${ }^{15}$ J. Huang, W. J. Poole, M. Militzer, Austenite formation during intercritical annealing, Metallurgical and Materials Transactions A, 35 (2004), 3363-3375, doi:10.1007/s11661-004-0173-x

${ }^{16}$ A. Karmakar, M. Ghosh, D. Chakrabarti, Cold-rolling and intercritical annealing of low-carbon steel: Effect of initial microstructure and heating-rate, Materials Science and Engineering A, 564 (2013), 389-399, doi:10.1016/j.msea.2012.11.109
${ }^{17}$ R. R. Mohanty, O. a. Girina, N. M. Fonstein, Effect of heating rate on the austenite formation in low-carbon high-strength steels annealed in the intercritical region, Metallurgical and Materials Transactions A, 42 (2011), 3680-3690, doi:10.1007/s11661-011-0753-5

${ }^{18}$ A. Chbihi, D. Barbier, L. Germain, A. Hazotte, M. Goune, Interactions between ferrite recrystallization and austenite formation in high-strength steels, Journal of Materials Science, 49 (2014), 3608-3621, doi:10.1007/s10853-014-8029-2

${ }^{19}$ F. Khodabakhshi, M. Kazeminezhad, A. H. Kokabi, Constrained groove pressing of low carbon steel: Nano-structure and mechanical properties, Materials Science and Engineering A, 527 (2010), 4043-4049, doi:10.1016/j.msea.2010.03.005

${ }^{20}$ F. Khodabakhshi, M. Kazeminezhad, The effect of constrained groove pressing on grain size, dislocation density and electrical resistivity of low carbon steel, Materials and Design, 32 (2011), 3280-3286, doi:10.1016/j.matdes.2011.02.032

${ }^{21}$ C. Lesch, W. Bleak, P. Alvarez, Grain refinement of cold rolled microalloyed steels by rapid transformation annealing, Luxembourg, 2006

${ }^{22}$ N. Peranio, Y. Li, F. Roters, D. Raabe, Microstructure and texture evolution in dual-phase steels: Competition between recovery, recrystallization, and phase transformation, Materials Science and Engineering A, 527 (2010), 4161-4168, doi:10.1016/j.msea.2010. 03.028

${ }^{23}$ E. Gutiérrez C., A. Salinas-Rodríguez, E. Nava-Vázquez, Effect of Fast Annealing on Microstructure and Mechanical Properties of Non-Oriented Al-Si Low C Electrical Steels, Materials Science Forum, 560 (2007), 29-34, doi:10.4028/www.scientific.net/MSF. 560.29

${ }^{24}$ A. Karmakar, A. Karani, S. Patra, D. Chakrabarti, Development of Bimodal Ferrite-Grain Structures in Low-Carbon Steel Using Rapid Intercritical Annealing, Metallurgical and Materials Transactions A, 44 (2013), 2041-2052, doi:10.1007/s11661-012-1556-Z 